\title{
アクリル酸エステルおよびメタクリル酸エステル系ポプコン重合*1, *2
}

(昭和 43 年 4 月 30 日受理)

瀬尾 邦昭*3 ·吉田弘*4 尾形 強*4 猪川 三郎*4

\begin{abstract}
フクリル酸エステルおよびメタクリル酸エステル系ポプコン重合について研究した。以下の実験で, ポブコン重合は窒素気流中

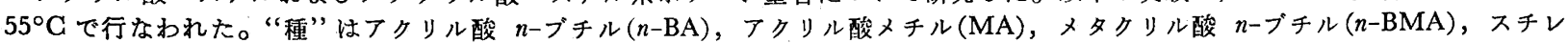
ンとエチレングリコール・ジフクリル酸エステル，ジェチレングリコール・ジフクリル酸エステル，エチレングリコール・ジメタ クリル酸エステル，ジエチレングリコール・ジメタクリル酸エステル，ジビニルベンゼンとの組み合わせでつくった。これらの種

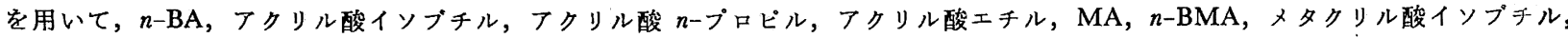
メタクリル酸エチル，MMA などがポブコン重合された。これらのポプコン重合の難易およびポブコン重合物の生長速度が測定 された。ポプコン重合はジフェニルピクリルヒドラジルが存在していても起こった。実験結果からポプ.ン重合は, 網目の内部に 埋蔵されているラジカルによって開始され，生成するポリマーの圧力によって網目が切断されてラジカルが新生し，反応が促進さ れることがわかった。このラジカル新生の難易は網目の分枝度に依存するように思われる。
\end{abstract}

\section{1 緒言}

前報1)で著者らは スチレン $(\mathrm{St})$-ジビニルベンゼン $(\mathrm{DVB})$ 系ポ プコン重合について研究し，ポプコン重合は網目構造の内部に埋 蔵されているラジカルにモノマーが達して重合が起こり，生ずる 重合物の機械的圧力によって主鎖や架橋が切断され，そのラジカ ルでさらに重合が促進されて起こることを述べた。本報では，主 としてアクリル酸エステルおよびメタクリル酸エステル系ポプコ ン重合物について研究を行ない，二三の新知見をえたので報告す る。

\section{2 実験結果および考察}

\section{1 “種”およびモノマーの種類とポプコン生成の難易}

$\mathrm{St}$-DVB(DVB, 0.5\%*5), St一モノエチレングリコール ジアク リル酸エステル(EGDA) (EGDA，2.5\%)，アクリル酸 $n$-ブチル (n-BA)-EGDA(EGDA，10\%)，n-BAージエチレングリコール ジアクリル酸エステル(DEGDA) (DEGDA，1\%), アクリル酸メ チル(MA)-EGDA(EGDA, 7.5\%)，メタクリル酸 $n$-ブチル $(n-$ BMA)-EGDA(EGDE，10\%)，n-BMAーエチレングリコール ジタクリル酸エステル(EGDMA) (EGDMA, 6.25\%),n-BA一 EGDMA(EGDMA，15\%)系ポプコン重合物をつくり，これらを 砕いて“種”として $0.4 \mathrm{~g}$ とり，この種に $n$-BA，アクリル酸イ

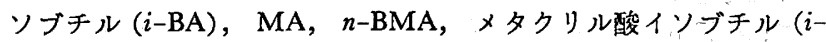

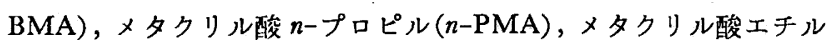
(EMA), メタクリル酸メチル(MMA)をモノマーとして $4.0 \mathrm{ml}$ 加え，ポプコン重合を行なったところ表 1 の結果をえた。すなわ

*1この報交を“ポプコン重合に関する研究(第 2 報)”とす る.

*2 前報(第 1 報), 猪川三郎, 大城禧一，尾形 強, 吉田 弘, 永兽和郎, 日化, 87, 1039(1966).

*3 Kuniaki SEo 沼津工業高等専門学校工業化学科, 沼津 市大岡

*4 Hiroshi Yoshida, Tsuyoshi Ogata, Saburo Inokawa 静岡大学工学部合成化学科, 捠松市城北

1）前報 (第 1 報), 猪川三郎, 大城㦷一, 尾形 強, 吉田 弘，永溒和郎，日化，87，1039(1966).

*5 St-DVB 混合物中の DVB の含有量が 0.5\% である ととを示するのとする.
ち，(1) 種の増殖性には，種をつくるとき用いた架橋郕成分の種 類で，EGDA，EGDMA，DEGDA の三者の間にあまり差がな い。（2）種のモノマー成分としては $n$-BMA がよい。（3）一般 にメタクリル酸エステル (MMA を除く) はアクリル酸エステル よりもポプコン重合しやすい。(4) アクリル酸エステルでは MA がもっともよい。(5) Breitenbach2 は MMA には $\alpha$-水素がな いため，ポプコン重合しないといっているが $n$-BMA-EGDMA 系，St-DVB 系の種を用いるとポプコン重合することがわかっ た。MMA の結果は興味があるので，さらに，i-BA-EGDMA (EGDMA, 10\%), MA-EGDMA(EGDMA, 6.25\%), n-BAジエチレングリコール ジメタクリル酸 エステル (DEGDMA) (DEGDMA，10\%) 系のポプコン重合物を種として，MMA が ポプコン重合するか否かを調べ，表 2 の結果をえた。種の架橋郕 成分に EGDMA，DEGDMA を用いた種はポプコン重合をつく るが，架橋侴成分に EGDA，DEGDA を用いた種はポプコン 重合をつくらないことがわかった。この理由はよくわからないの で，今後さらに研究を進める予定である。

\section{2 ポプコン重合に適する架橋剛の䉥度範囲}

n-BA-EGDA(EGDA，10\%)系ポプコン重合物 $0.1 \mathrm{~g}$ を種と して用い，種々のモノマーに種々の架橋郕を種々の濃度添加し， ポプコン重合する架橋郕の浱度範囲を求めたところ表 3 に示すよ うになった。また，これらのポプコン重合物を砕いて，アセト ン，ベンゼン，トルエンなどでホモポリマーの抽出を試みたが， 完全なポプコン重合物中には，ホモポリマーはほとえど存在しな かった。この表からつぎのことがいえる。(1) 完全なポプコン重 合物を与える架橋郕の濃度範囲は, 主としてエステルのアルコー ル基の違いによって変化し, 架橋剤の種類にはあまりよらない。 （2）モノマーがアクリル酸系, 架橋刘がメタクリル酸系のような 混合系では, ポプコン重合物は不完全である。(3) 種に $n$-BA一 EGDA 系ポプコン重合物を用いた場合には，架橋戍の量に関係 なく, MMA はポプコン重合しない。

\section{3 ポプコン重合物の生長速度}

2.3 .1 種 および モノマーの種類による影響：種に $n$-BAEGDA (EGDA, 10\%), n-BA-EGDMA(EGDMA, 10\%), n2) J. W. Breitenbach, H. Dworak, J. Polymer Sci., 4,
1328(1966). 
表 1 種とモノ マ 一 と増 殖性

\begin{tabular}{|c|c|c|c|c|c|c|c|c|}
\hline จ- & $\begin{array}{l}\text { St-DVB } \\
(0.5)^{a)}\end{array}$ & $\begin{array}{c}\mathrm{St}-\text { EGDA } \\
(2.5)\end{array}$ & $\begin{array}{c}n-\mathrm{BA}-\mathrm{EGDA} \\
\frac{(10)}{}\end{array}$ & $\begin{array}{l}n-\mathrm{DA}- \\
\text { DEGDA } \\
\quad(10)\end{array}$ & $\underset{(7.5)}{\text { MA_EGDA }}$ & $\begin{array}{c}n \text {-BMA- } \\
\text { EGDA } \\
\quad(10)\end{array}$ & $\begin{array}{c}n-\mathrm{BMA}- \\
\mathrm{EGDMA} \\
(6.25)\end{array}$ & $\begin{array}{l}\text { EGDMA } \\
\quad(15)\end{array}$ \\
\hline$n-\mathrm{BA}$ & $\Delta$ & $\Delta$ & $\Delta$ & $\Delta$ & $\Delta$ & 0 & オまたは○ & - \\
\hline$i-\mathrm{BA}$ & $\Delta$ & $\Delta$ & $\Delta$ & $\Delta$ & $\triangle$ & 0 & メまたは○ & $\dot{-}$ \\
\hline MA & 0 & 0 & 0 & $\Delta$ & 0 & 0 & 0 & - \\
\hline$n$-BMA & 0 & 0 & 0 & 0 & 0 & 0 & $\mathrm{O}$ & $\mathrm{O}$ \\
\hline$i-\mathrm{BMA}$ & 0 & $\Delta$ & 0 & 0. & 0 & 0 & $\mathrm{O}$ & 0 \\
\hline$n$-PMA & 0 & 0 & 0 & 0 & 0 & 0 & 0 & 0 \\
\hline EMA & 0 & 0 & 0 & 0 & 0 & 0 & $\mathrm{O}$ & 0 \\
\hline MMA & 0 & $x$ & $x$ & $x$ & $x$ & $x$ & 0 & 0 \\
\hline
\end{tabular}

注 ○印は完全なポプコン重合物，、印は不完全なポプコン重合物，メ印はポブコン重合しないことを示す。

種は $0.4 \mathrm{~g}$ ，種に加えたモノマーは $4.0 \mathrm{ml}$ 用いた.

a）（）内は種中に含まれる架橋剂のパーセントを示す.

表 2 MMA のボブコン重合性と種の種類

$$
\text { 種 }
$$

$\begin{array}{lc}n \text {-BMA-EGDMA } & 6.25 \\ n \text {-BA-EGDMA } & 15 \\ i \text {-BA-EGDMA } & 10 \\ \text { MA-EGDMA } & 6.25 \\ n \text {-BA-DEGDMA } & 10 \\ \text { St-DVB } & 0.5 \\ \text { St-EGDA } & 2.5 \\ n \text {-BA-EGDA } & 10 \\ \text { MA-EGDA } & 7.5 \\ n \text {-BMA-EGDA } & 10 \\ n \text {-BA-DEGDA } & 10\end{array}$

BMA-EGDMA(EGDMA, 6.25\%), St-DVB(DVB, 0.5\%) を種々の量を用い，モノマーとして $n$-BA，n-BMA， MMA， St を用いて，膨張計によってポプコン重合物の生長速度を測定し た。その結果を図 1〜4 に示した。n-BA，n-BMA，St では重 合開始後しばらくののち最大生長速度を示し, やがて速度がおそ くなり，モノマーが十分多量に存在するときにはモノマーを残し て重合は停止する*6。MMA のみは少しようすが薏い，初期生 長速度が最大で，徐々に括とくなり，やがて停止した。図 1 〜 から元られ初期生長速度および最大生長速度をまとめると表 4 のようになる。種の量と生長速度との間に注図 5, 6 に示すよう に直線関係が成立している。初期生長速度は，種の量を 0 まで外 抻すると 0 点を通るが，最大生長速度は 0 点を通らない。これら のことは，ポプコン重合は種の中に残っているラジカルによって

注 種は $0.4 \mathrm{~g}$ ，種に加えたモノマーは $4.0 \mathrm{ml}$ 用いた。

ポプコン重
合の有無
0
0
0
0
0
$\bigcirc$
$\times$
$\times$
$\times$
$\times$
$\times$

\section{表 3 ポプコン重合物をつくる架橋片の濃度範囲}

\section{架橋削添加量 $(\%)$}

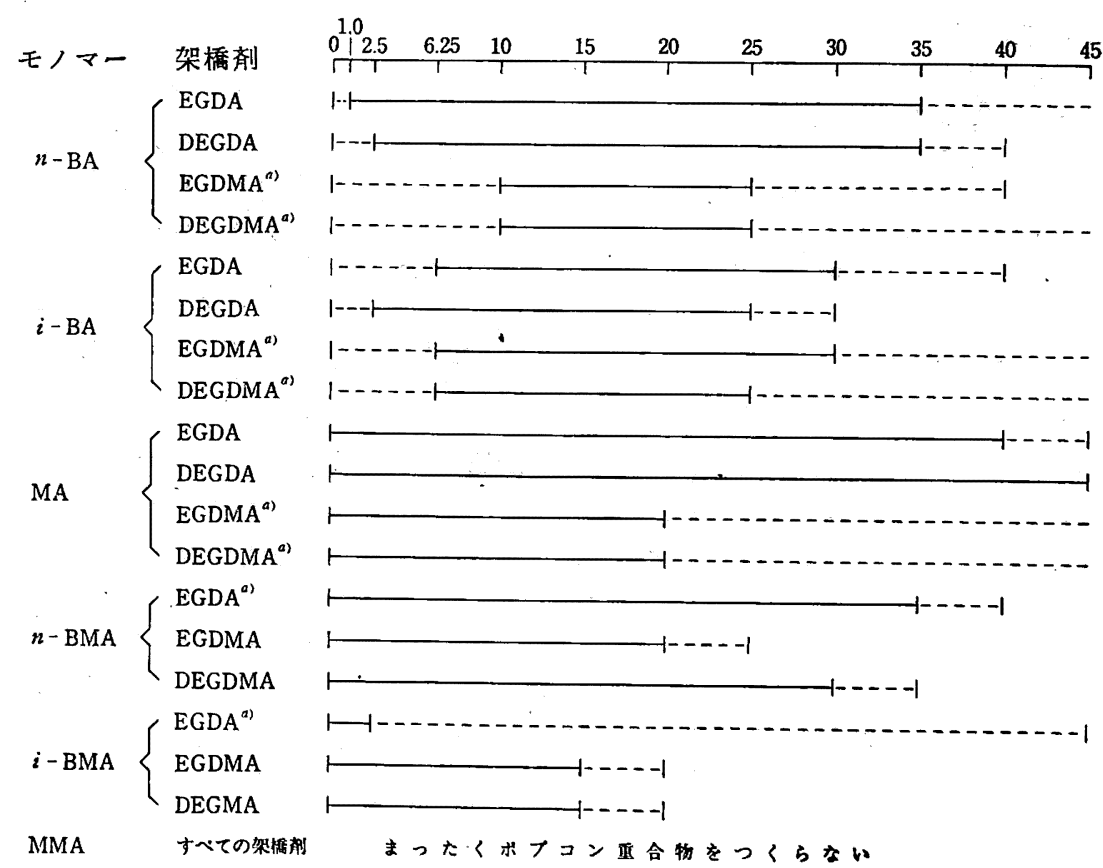

注 ----: 不完全なポブコン重合，一：完全なポプコン重合を示す.

種に $n$-BA-EGDA(EGDA，10\%)系ボブコン重合物 $0.1 \mathrm{~g}$ を，モノマーは $4.0 \mathrm{ml}$ 用いた.

a) 一般にポプコン重合の状態が悪く, 不完全と完全なポプコン重合との区別がつけにくかった. 


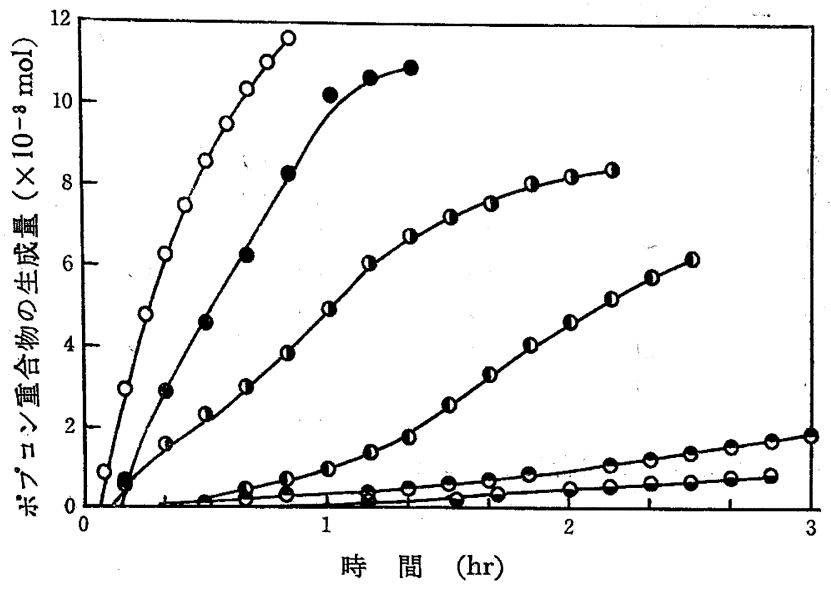

種の量 $(\mathrm{g})$ とモノマーの種類一
(1) $0.10, \mathrm{MMA}$,
๑: $0.25, \mathrm{MMA}$,
O: 0.5, MMA
D: $0.10, n-\mathrm{BMA}$,
$\theta: 0.10, \mathrm{St}$,
$\ominus: 0.10, n$-BA

図 $1 n$-BA-EGDMA(EGDMA，10\%)系ポプコン重合物 を種としたときの生長曲線

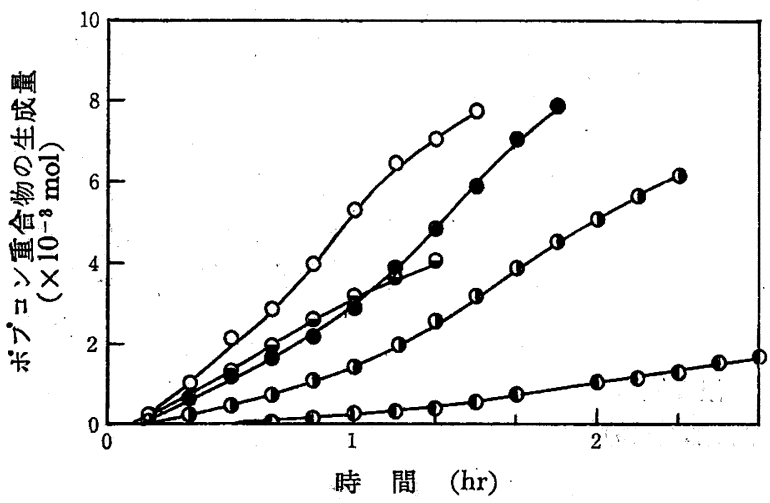

種の量 $(\mathrm{g})$ とモノマーの種類——

): $0.10, n-\mathrm{BA}, \quad \bigcirc: 0.25, n-\mathrm{BA}, \quad \bigcirc: 0.50, n-\mathrm{BA}$

$\ominus: 0.10, n$-BMA, $\mathrm{D}: 0.10, \mathrm{St}$

因 2 n-BA一EGDA(EGDA，10\%)系ポブコン

重合物を種としたときの生長曲線

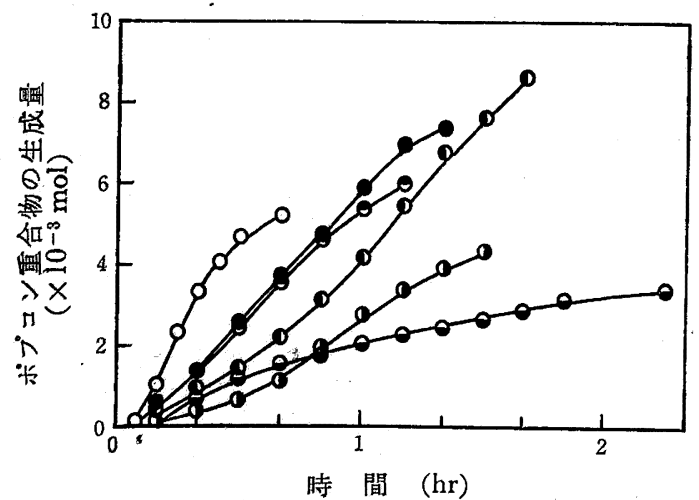

種の量 $(\mathrm{g})$ とモノマーの種類——
(1) $0.025, n$-BMA,
$\mathrm{O}: 0.10, n-\mathrm{BMA}$,
: $0.05, n$-BMA
$\Theta: 0.10$, St,
D: $0.10, n-\mathrm{BA}$
○: 0.10, MMA

図 3 n-BMA-EGDMA(EGDMA，6.25\%)系ポプコン

重合物を種としたときの生長曲線

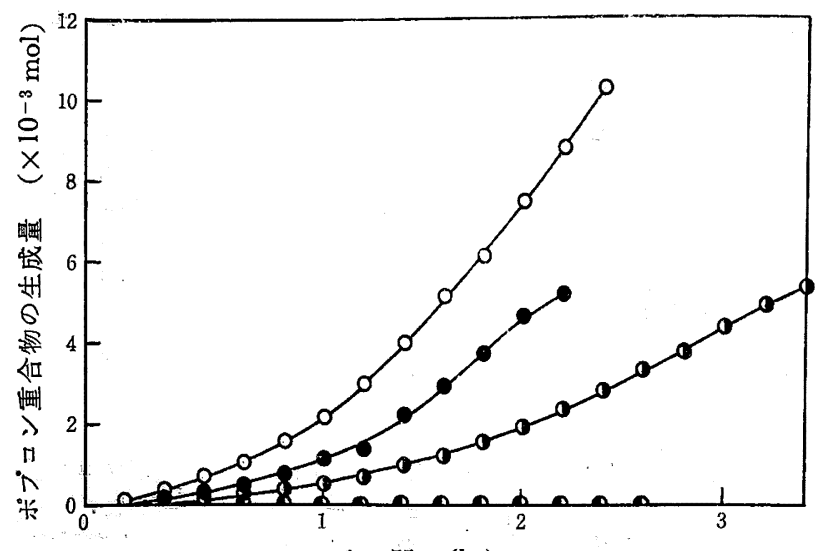

特 間 $(\mathrm{hr})$

種の量 $(\mathrm{g})$ とモノーの種類—

(1) $0.10, \mathrm{St}$

$0.25, \mathrm{St}$

$\mathrm{O}: 0.5, \mathrm{St}$,

D: $0.10, n$-BMA

図 $4 \mathrm{St}$-DVB(DVB，0:5\%)系ポプコン重合物を

種としたときの生長曲線

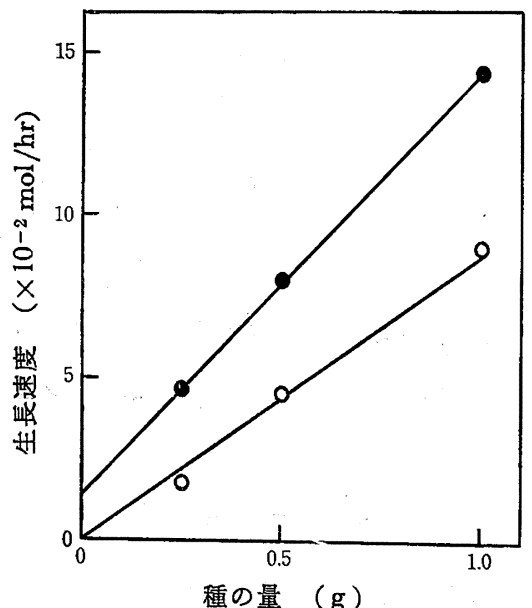

最大生長速度 (種, n-BMA-EGDMA(EGDMA $6.25 \%)$, モノマー $n$-BMA)

O: 初期生長速度 (種, n-BMA-EGDMA(EGDMA $6.25 \%)$, モノマー $n$-BMA)

図 5 種の量と初期生長速度および最大生長速度との関係

開始され，重合が進むにつれて新しいラジカルが生成し，重合が 促進され，種に加えたモノマーが架橋剤を含まないときにはやが てラジカルの生成がとまり重合が停止する，ことを示すと思われ る。 MMAがポプコン重合をつくりにくいのは，このラジカル の新生が少ないためと思われる。

2.3 .2 種中の架橋㧩含有量の影響: DVB を $0.1,0.4,1.0$, $1.5 \%$ 含む St-DVB 系ポプコン重合物を種とし, St 重合させて図 7 亿示す生長曲線をえた。種中の DVB の量が 1.0 \% までは DVB 含有量が増すと最大生長速度も増すが, $1.5 \%$ では逆に減少するととがわかった。すなわち種の中の架橋が多す ぎても，少なくてもラジカルの生成が減少するように思われる。

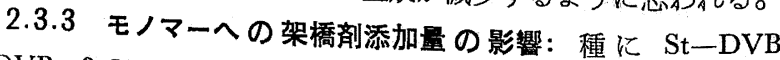
(DVB， 0.5\%)系ポプコン重合物を $0.05 \mathrm{~g}$ 用い，種々の量の DVB 它含さ St をポプコン重合させたところ図 8 のようになっ 


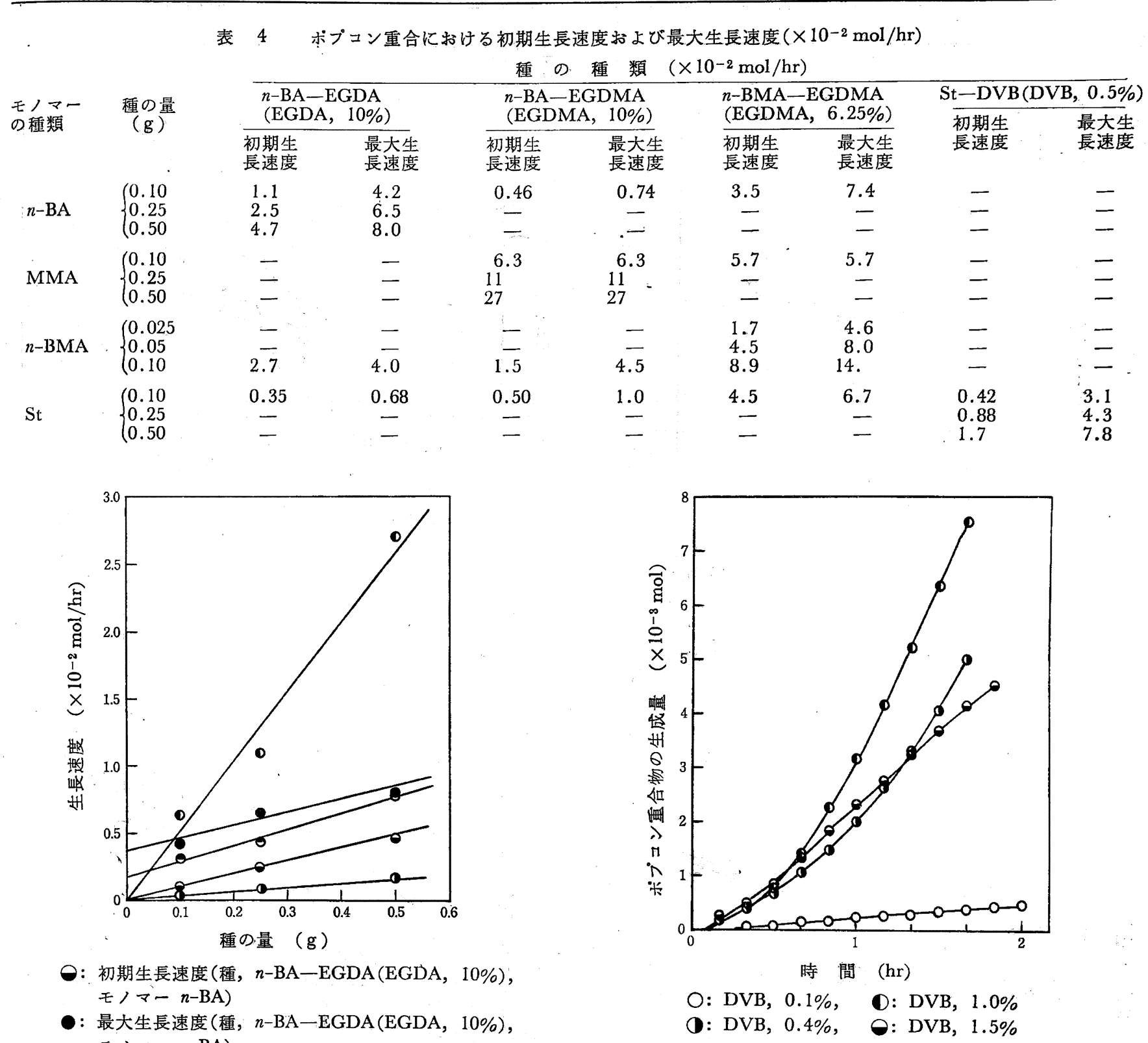
モノマー $n$-BA)

D：初期および最大生長速度(種，n-BA-EGDMA (EGDMA, 10\%), モノマー MMA)

図 7 DVB の量をことにする St一DVB 系ポプコン重合物 を種とした St の生長曲線

○：初期生長速度(種, St-DVB (DVB，0.5\%), モノマー $\mathrm{St}$ )

○: 最大生長速度(種, St-DVB(DVB, 0.5\%), モノマ- St)

図 6 種の量と初期生長速度および最大生長速度との関係

た。この場合は，モノマーが消費されるまで生長速度はほぼ一定 であった。これはモノマー中に適量の架橋戍が存在するときに は，ラジカルの 新生がいつまでもつづくためと思われる。DVB の量が $0.6 \%$ までは DVB の量が增すと生長速度も增すが， 1.0 \% 以上では逆に減少することがわかった゚すなわち，ラジカル の新生は架橋戍が多すぎても, 少なくても減少すると考兄られる。

2.3 .4 ジフェニルピクリルヒドラジル (DPPH) 添加 の影響:

種として $n$-BA-EGDA (EGDA， 10\%)，n-BA-EGDMA (EGDMA, 10\%), St-DVB(DVB， 0.5\%)系ポプコン重合物を $0.25 \mathrm{~g}$ 用い, モノマーとして $n$-BA, MMA, St に DPPH 老 $0.25 \times 10^{-3} \sim 5.0 \times 10^{-2} \mathrm{~g} / l$ 添加して使用し, 生長速度を測定す

ると図 9〜11 のようになった。それらの初期生長速度および最 大生長速度を表 5 に示した。生長曲線の形は DPPH を添加しな いときとほぼ同じであった。DPPH の濃度が高くなるほど重合 はおそくなるが，DPPH の色が残っていてむ重合は進行するこ とがわかった。また，かきまぜても生長速度には変化がみ、られな からた。すなわち，重合は網目構造をもったポプコン重合物の内 部で起こっていると思われる。

\subsection{5 種の酸化窒素ガス処理の影響: $n$-BA-EGDA(EGDA,} 10\%), n-BA-EGDMA(EGDMA, 10\%), n-BMA-EGDMA (EGDMA， 6.25\%)，St-DVB(DVB，0.5\%)系ポプコン重合物 からつくった種を酸化窒素ガス処理後, それぞれ $n$-BA, $n-\mathrm{BMA}$, MMA，St を加えてポプコン重合させたところ，St-DVB 系の 種は St をポプコン重合させる能力を失っていた。その他の種で は図 12 に示すように, n-BA-EGDMA および n-BA-EGDA 系の種は $n$-BA をほとんど処理前と同じ速度で, また, $n$-BMA一 EGDMA 系の種は $n$-BMA を，速度はかなりおをくなるが，ポ 


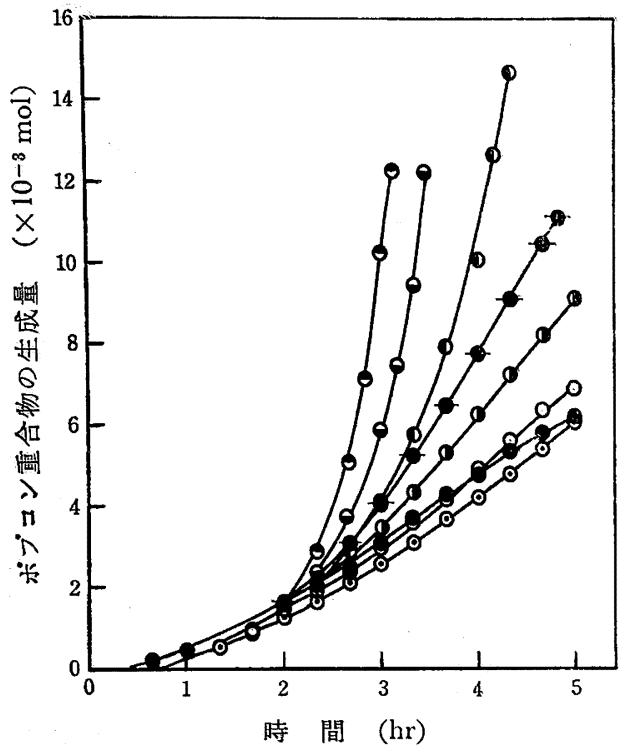

DVB の含有量 $(\%)-$
○: 0 ,
(1) 0.05 ,
○: 0.6 ,
: 1.0 ,
D: 0.2 ,
$\ominus: 0.4$

図 $8 \mathrm{St}-\mathrm{DVB}(\mathrm{DVB}, 0.5 \%)$ 系ポプコン重合物を 種とした St一DVB 系ポプコン生長曲線

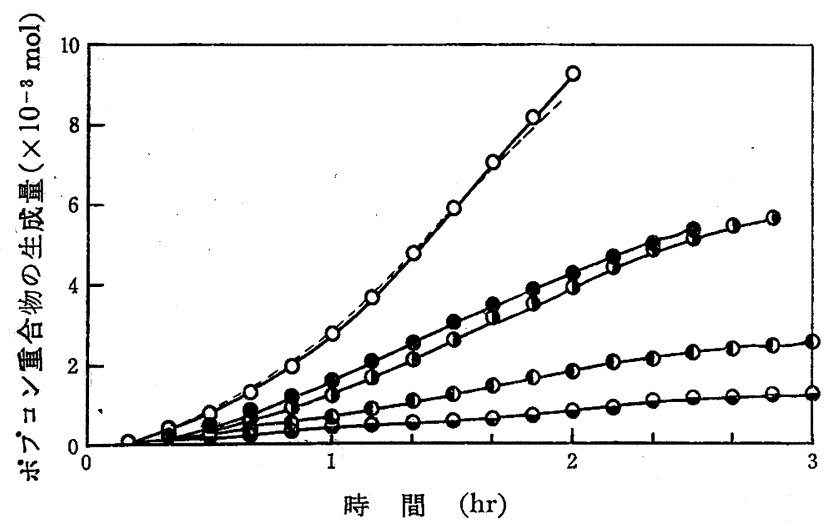

DPPH 量 $\left(\times 10^{-6} \mathrm{~mol} / l\right)($ 種の量は $0.25 \mathrm{~g})-$

$\bigcirc: 0.63, \bigcirc: 3.17, \bigcirc: 12.7, \bigcirc: 31.7, \ominus: 63.5$

比較のため.DPPH を含まないときの生長曲線を----で 併記した。

図 $9 n$-BA-EGDA(EGDA，10\%)系ポプコン重合物を 種としたときの $\mathrm{DPPH}$ を含む $n$-BA の生長曲線

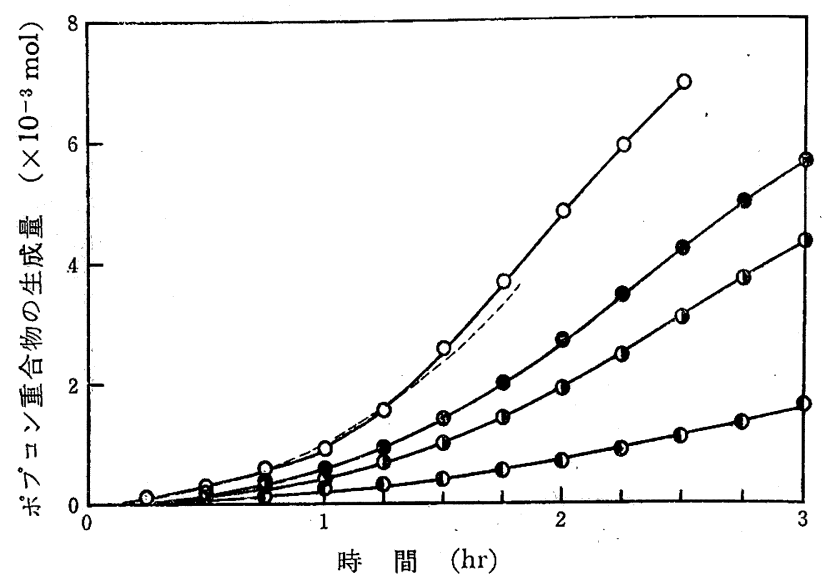

DPPH 量 $\left(\times 10^{-6} \mathrm{~mol} / \mathrm{l}\right)$ (種の量は $\left.0.25 \mathrm{~g}\right)$ ○: $12.7, \quad \bigcirc: 31.7, \quad(1) 47.6, \quad$ ( $: 63.5$ 比較のため DPPH を含まないときの生長曲線を---で併記した。

図 $10 \mathrm{St}-\mathrm{DVB}(\mathrm{DVB}, 0.5 \%)$ 采ポプコン重合物を 種としたときの DPPH を含む St の生長曲線

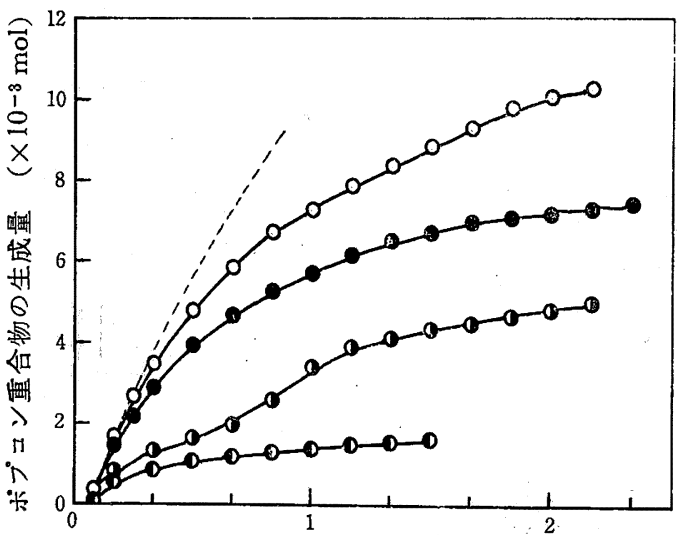

時 間 $(h r)$

DPPH 量 $\left(\times 10^{-6} \mathrm{~mol} / \mathrm{l}\right)($ 種の量は $0.25 \mathrm{~g})$ ○: $1.27, \quad 0: 12.7, \quad$ ○: $31.7, \quad 0: 127$ 比較のため $\mathrm{DPPH}$ を含まないときの 生長曲線を -ーーで併記した。

図11n-BA-EGDMA(EGDMA，10\%)系ポプコン重合物 を種としたときの DPPH を含む MMA の生長曲線

表 5 モノマーに DPPH を添加したときのポブコン重合の初期生長速度および最大生長速度 $\left(\times 10^{-2} \mathrm{~mol} / \mathrm{hr}\right)$

】種の種類 $n-\mathrm{BA}-\mathrm{EGDA}(\mathrm{EGDA}, 10 \%)$

DPPH の量〉の種額 $\left(\times 10^{-6} \mathrm{~mol} / l\right)$

$\begin{array}{lcc}0 & 2.5 & 6.5 \\ 0.63 & - & - \\ 1.3 & - & - \\ 3.2 & 1.5 & 3.0 \\ 12.7 & 1.1 & 2.9 \\ 31.7 & 0.52 & 1.2 \\ 47.6 & - & - \\ 63.5 & 0.34 & 0.59\end{array}$

$$
\text { 初期 }
$$

期生長速度最大生長速度

$-$

\begin{tabular}{cc}
\multicolumn{2}{c}{$\mathrm{St}-\mathrm{DVB}(\mathrm{DVB}}$, \\
$\mathrm{St}$ & $0.5 \%)$ \\
\hline 初期生長速度 & 最大生長速度 \\
0.88 & 4.3 \\
- & - \\
- & - \\
- & - \\
0.57 & 3.2 \\
0.46 & 2.3 \\
0.35 & 1.2 \\
0.19 & 0.57 \\
- & -
\end{tabular}

$n$-BA-EGDMA(EGDMA, 10\%)
MMA

初期生長速度 最大生長速度

\begin{tabular}{cc}
11 & 11 \\
-12 & - \\
- & 12 \\
9.9 & - \\
4.8 & 9.9 \\
- & 4.8 \\
- & - \\
2.8 & - \\
\hline
\end{tabular}

注種は $0.25 \mathrm{~g}$ 使用した。 
プコン重合させることがわかった。このことはガスの浸透性の差 认よるものと思われ, St-DVB ポプコン重合物中のラジカルは酸 化窒素ガスによって完全に消滅するが，n-BA-EGDA，n-BA一 EGDMA，n-BMA-EGDMA ポプコン重合物では, ラジカルが 残るためであろう。

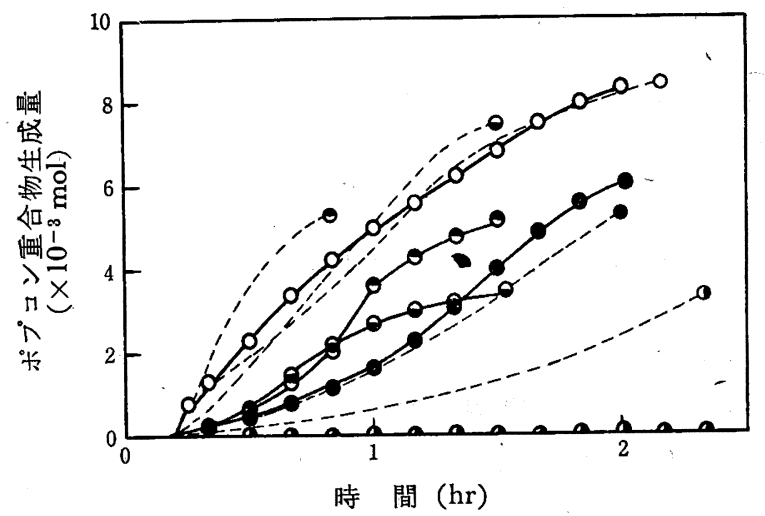

種の種類, 量 $(\mathrm{g})$, モノマーの種類一

- : $n$-BA-EGDA(EGDA, 10\%), 0.10, n-BA

: $n$-BMA-EGDMA(EGDMA, $6.25 \%), 0.05, n$-BMA

๑: $n$-BMA-EGDMA(EGDMA, $6.25 \%), 0.10, n$-BMA

(1) $\mathrm{St}-\mathrm{DVB}(\mathrm{DVB}, 0.5 \%), 0.10, \mathrm{St}$

O: n-BA-EGDMA(EGDMA, 10\%), 0.10, MMA

比較のため酸化窒素で処理しないときの生長曲線をそれぞれ

--.-ーで併記した。

困 12 種を酸化窒素で処理したときの生長曲線

以上の実験結果を総合して考えると，ポプコン重合物中には， 網目の内部深くにラジカルが埋蔵されており，そこにモノマー が達して重合が開始される。ついで新しく生じた重合物の圧力の ために，網目が切断されてラジカルが新生し，重合が 促進され る。この網目の切断の容易さは架橋の量に依存し，架橋が多すぎ ても，少なくても網目は切断されにくくなる。おそらく架橋が少 ないときには生成するポリマーによる圧力がかかりにくく，また 網目が多くなりすぎるとモノマーの浸透が防害され，さらに網目 が強くなりすぎて切断が困難になるためではないかと思われる。 なお，ポプコン重合の難易には，連鎖移動の問題が大きな役割を 持つようであり，今後研究を進めていきたいと思う。

\section{3 実験}

\section{1 試 䕓}

$i$-BA， $i$-BMA： 相当する酸とイソブチルアルコールをトルエ
ン中で硫酸を触媒として合成しだ3。

$n$-PA， $n$-PMA：相当する酸のメチルエステルと1-プロパノー ルから合成したは。

$n$-BA，EA，MA，n-BMA，EMA，MMA，St，DVB：市販 品を $5 \%$ 水酸化ナトリウム水溶液で重合防止刜を除いたのち常法 で精製したらう。

EGDA，DEGDA，EGDMA，DEGDMA：相当する酸とグリ コニルとをトルェン中で直接エステル化して合成した。それらの 沸点, $n_{\mathrm{D}}^{29}$ をつぎに示す。

$\begin{array}{lcc}\text { モノマー } & \text { 沸点 }\left({ }^{\circ} \mathrm{C} / \mathrm{mmHg}\right) & n_{\mathrm{D}}^{29} \\ \text { EGDA } & 66 \sim 68 / 1 & 1.4445 \\ \text { DEGDA } & 96 / 1 & 1.4494 \\ \text { EGDMA } & 76 \sim 77 / 0.5 \sim 1 & 1.4472 \\ \text { DEGDMA } & 112 \sim 113 / 0.5 \sim 1 & 1.4468\end{array}$

その他の試薬：市販品を常法によって精製した。

\section{2 種のポプコン重合物の製法}

精製したモノマー $4.0 \mathrm{ml}$ に適量の架橋坽をを加え, 3 分間窒素 を通したのち, 窒素を通しながら封管し, $55^{\circ} \mathrm{C}$ の恒温器中で加 熱した。

\section{3 種を用いるポプコン重合物の製法}

三方コックをつけ試験管を用い，前報りと同様にして 行なっ た。

\section{4 ポプコン生長速度の測定}

三方コックと側管のついた膨張計を用い，側管から粉末にした 種を入れて側管を封じ， 3.3 にしたがってモノマーを三方コック から注入し, 封管ののち, $55^{\circ} \mathrm{C}$ の恒温槽に入れ常法にしたがっ て測定した。

\section{5 酸化窒素による種の処理}

三方コックをつけた反応管中に粉末にした種を入れ，3.3 と同 様にして管内を窒素ガスで置換したのち減圧にし，酸化窒素を導 入乙, 窒温で 24 時間放置ののち, 高真空で酸化窒素を 除去し た。

終りに，研究費を援助下さった旭硝子工業技術奖励会に深く感 謝を申し上げます。

(1968 年 3 月, 日本化学会第 21 年会講演)

3) 神原 周編, “高分子実験学講座 (第 9 巻) 単量体の合成 法”，共立 (1964)p. 147.

4) O. Kamm, G. S. Marvel, "Organic Syntheses", (1948) Coll. Vol. II , p. 146.

5) 交献 3 )の p. 72, 140. 